\title{
Balneotherapy in the era of COVID-19: should it be recommended or not?
}

\author{
Orhan Guvener ${ }^{1}$ (D)
}

Received: 21 April 2020 /Revised: 25 April 2020 / Accepted: 26 May 2020 / Published online: 4 June 2020

(C) ISB 2020

To Editor,

I read a recently published report by Masiero et al. (2020) in your reputed journal with great interest. I thank the authors for their important remarks that remind us of the benefits of balneotherapy on human immune function.

I have a few doubts concerning their suggestion. First of all, I cannot fully support the advice that spas can be visited for balneotherapy purposes in COVID-19 days. While I share the view that balneotherapy hydrotherapy applications can alter the human immune system, I also think that they may have a yet unknown effect on the virus itself and virus transmission (Masiero et al. 2020). There are studies that examine the relationship between COVID-19 incidence and a number of meteorological factors worldwide. Absolute air temperature and humidity have been reported to affect COVID-19 transmission among patients. Unfortunately, the results of these recent studies are variable (Liu et al. 2020; Tosepu et al. 2020). Furthermore, it is well known that the viral transmission begins before symptoms arise. Close contact with someone during these asymptomatic but contagious periods raises the risk of infection and disease transmission (Siordia Jr 2020). So even though the precautions are taken, people will still come together around hot springs or in pools in these facilities. Also, it must be kept in mind that this spa population will mostly be older people and/or having chronic diseases and drug use.

Last but not least, we know that balneotherapy has thermal effects on the body; hot water causes vasodilation (Nasermoaddeli and Kagamimori 2005). Acute inflammation exacerbates in the presence of heat-induced vasodilation
(Ozturk 2004). Therefore, inflammation may accelerate in asymptomatic but infected people.

Like many other health issues in these days, spa usage and balneotherapy may be a risk for patients in the abovementioned points, so cons and pros must be carefully evaluated for each patient.

\section{References}

Liu J, Zhou J, Yao J, Zhang X, Li L, Xu X, He X, Wang B, Fu S, Niu T, Yan J, Shi Y, Ren X, Niu J, Zhu W, Li S, Luo B, Zhang K (2020) Impact of meteorological factors on the COVID-19 transmission: a multi-city study in China. Sci Total Environ 726:138513. https://doi. org/10.1016/j.scitotenv.2020.138513

Masiero S, Maccarone MC, Magro G (2020) Balneotherapy and human immune function in the era of COVID-19. Int J Biometeorol. https:// doi.org/10.1007/s00484-020-01914-z

Nasermoaddeli A, Kagamimori S (2005) Balneotherapy in medicine: a review. Environ Health Prev Med 10(4):171-179

Ozturk C (2004) Tedavide sıcak ve soğuk. In: Oğuz H (ed) Tıbbi Rehabilitasyon, 2nd edn, İstanbul, pp 181-200

Siordia JA Jr (2020) Epidemiology and clinical features of COVID-19: a review of current literature. J Clin Virol 127:104357. https://doi.org/ 10.1016/j.jcv.2020.104357

Tosepu R, Gunawan J, Effendy DS, Ahmad LOAI, Lestari H, Bahar H, Asfian P (2020) Correlation between weather and Covid-19 pandemic in Jakarta, Indonesia. Sci Total Environ 725:138436. https://doi.org/10.1016/j.scitotenv.2020.138436

Publisher's note Springer Nature remains neutral with regard to jurisdictional claims in published maps and institutional affiliations.

Orhan Guvener

dr.orhanguvener@gmail.com

1 Department of Physical Medicine and Rehabilitation, Mersin City Training and Research Hospital, 33240 Mersin, Turkey 